\title{
Crowdfunding in higher education: evidence from UK Universities
}

\author{
Hugo Horta ${ }^{1}$ (D) Michele Meoli $^{2}$ (D) . Silvio Vismara ${ }^{3}$ (D)
}

Accepted: 7 January 2021 / Published online: 17 March 2021

(c) The Author(s) 2021

\begin{abstract}
In contemporary higher education systems, funding is increasingly associated with performativity, assessment, and competition, and universities are seeking different forms of financing their activities. One of these new forms is crowdfunding, a tool enabled by the digitalization of finance. Based on data from the UK higher education system and two crowdfunding platforms, our study adds to previous crowdfunding research in academic settings that have, thus far, focused on research projects, and assesses who is participating, their level of engagement and the resources they have gathered from crowdfunding. Our findings show that crowdfunding is used more by universities that have fewer resources. These universities are more teaching-oriented, less prestigious, and have a student body largely derived from lower socio-economic sectors of society. The popularity of crowdfunding in this type of university suggests that crowdfunding may enhance the democratization of higher education funding. However, as optimal crowdfunding participation and engagement requires high academic-to-student ratios and total-staff-to-academic-staff ratios, universities facing a greater financial precarity may be disadvantaged in their access to and engagement with crowdfunding. Differentials between part-time and full-time student ratios may exacerbate this disadvantage. Our study suggests that crowdfunding is a viable means of obtaining additional financing for learning activities complementing the fundings from other sources, but raises concerns about the use of crowdfunding as a burden to academics and students to find resources to meet learning experiences that ought to be provided by universities in the first place.
\end{abstract}

Keywords Crowdfunding · Fundraising · Funding of higher education · Socioeconomic inequality $\cdot$ Financing of teaching and learning activities

\section{Introduction}

The funding of higher education has become of crucial importance as the worldwide demand for and participation in higher education has expanded at increasingly high rates (Teixeira $\&$ Landoni, 2017). Two main issues have put a spotlight on the funding of higher education.

Michele Meoli

michele.meoli@unibg.it

Extended author information available on the last page of the article 
First, increased government and public demand for higher education with the expectation of increased economic development and upward social mobility have led to substantially increased public expenditure in higher education. This has constrained public budgets in wealthier countries, in terms of both upkeep and investment, and presented a daunting challenge for poorer countries, opening the door to a broad range of privatization initiatives (Langa, 2017). The latter has affected higher education systems by involving the establishment of private higher education sectors and increased competition, marketization, and commodification of tertiary education. These privatization initiatives have also affected families' budgets as some of the participation costs in higher education were transferred to families, and financial instruments, such as student loans and vouchers, were devised to support the participation of students in higher education (Jongbloed \& Vossensteyn, 2016).

Second, as part of a strategy aimed at containing costs while maximizing benefits from investments and aligned with new public management ideals that shaped the state's functioning as a whole, many governments have adopted a "steering at a distance" stance concerning higher education institutions (HEIs). Thus, governments encourage HEIs to adopt managerial and corporate-style accountability practices, aimed at stimulating performativity and regular assessment (Ferlie et al., 2008). This change in governments' behavior towards HEIs was partly justified as a way to make higher education systems and institutions more transparent and accountable to the public, following a trend to make universities more responsive to societal challenges, open to collaboration with companies, more attentive to their students, and less akin to "ivory towers" (Law, 2019). This change was also part of an effort to create HEIs as more corporate-like and budget-efficient, although with nuances varying according to the extent of a government's neoliberal political leanings, understanding of tertiary education missions, appreciation of ideas for the public good, and socio-economic equity concerns over access and participation (Lepori \& Jongbloed, 2018). Although dominant, the neoliberal narrative is not universal, and in some countries no specific template of adopted policy instruments is identified (Capano \& Pritoni, 2020). Public policies concerning the funding of higher education still retain a central role and affect the quality of education and research, the structuring of higher education systems, and the linkage of HEIs with economic, cultural, and social systems (Holmwood \& Servós, 2019). The literature in this field points out that even though participation has not necessarily increased equity levels, qualification levels are higher than before, and participation in higher education is increasing (Wright \& Horta, 2018). Higher education systems are considered as increasingly commodified and functioning as quasi-markets driven by competition, student consumerism, positional goods, and credentialism (Naidoo \& Williams, 2015).

Although the literature offers a comprehensive perspective on funding in higher education, a new form of financing higher education-related activities has remained underexplored in the higher education literature: crowdfunding. Crowdfunding is a form of digital fundraising, whereby groups of people donate varying (and often relatively small) amounts of money to support a particular goal (Vismara, 2016). Crowdfunding is defined as an open call for financial resources either in form of a donation or in exchange for a reward and/or voting rights to support initiatives for specific purposes (Block et al., 2018). In the context of higher education, crowdfunding can be seen as a form of private funding diversification, complementing direct (tuition fees) and indirect (traditional fundraising) sources that are planned and driven by the university (Teixeira \& Koryakina, 2013). Crowdfunding shares some similarities with traditional fundraising models, but is fully internet-based, arguably fits the aspirations and fund availability of younger donors better, and is not necessarily led by universities but rather is driven by individual students and academics (Năstase, 2018). This funding mechanism is reportedly gathering momentum in higher education settings, but most studies have focused 
on crowdfunding related to research and research-related entrepreneurial initiatives (Sauermann et al., 2019) and to a lesser extent on teaching, wherein education-related start-ups have been examined (Antonenko et al., 2014).

Our study aims to fill this research gap by developing a more comprehensive understanding of the function of crowdfunding in higher education. This is done by assessing whether participation, engagement, and revenues from crowdfunding activities are related to specific university characteristics. We collected data from the crowdfunding platforms Hubbab and Justgiving, which focus on funding teaching, learning, and societal engagement projects initiated by students and staff based at UK universities. To assess how university characteristics such as student and staff bodies and financial position influence their engagement in crowdfunding activities, we augmented this dataset with data obtained from UK universities themselves. We selected the UK higher education system owing to its institutional diversity, student and staff heterogeneity, marketized higher education system, performativity drive, and HEI engagement in fundraising activities to complement public funding (Warren et al., 2016).

Our study is structured as follows. The next section presents a literature review about crowdfunding as a funding mechanism with a focus on higher education settings. We posit that a relationship may exist between the use of crowdfunding by universities and the current financial challenges that universities face. Next, the data and methods section presents the data collection procedure, the characteristics of the data, and the methods used for data analysis. In the results section, we present and discuss the findings. In the conclusions, we compare our main findings to those in the literature and suggest further avenues for research.

\section{Crowdfunding and its current use in higher education settings}

The development of the internet and social media in modern, globalized societies has fuelled an enormous growth in low-cost global communication and has expanded how people can engage in activities (Rifkin, 2014). Crowdfunding is a more recent development where a proponent (a single individual, a team, or an organization) creates a call directed to the public at large and asks for a specific project to be funded. Via the internet, projects tend to be funded by a relatively large number of people who contribute relatively small amounts; thus, the entire funding source is dependent on a large number of small contributions (Mollick, 2014). This is an increasingly popular practice for funding projects in many sectors of the society and economy. For instance, crowdfunding is revolutionizing the gaming industry, permitting small-scale studios and sole programmers to launch proposals for "kickstart" (new) games thereby transforming gamers from consumers to prosumer-investors (Planells, 2017). Medical crowdfunding is also rapidly growing in many countries as a way to cope with government health budget cuts. Bassani et al. (2019) explore the relationship between healthcare crowdfunding and national health systems and found evidence of a substitution effect when public health coverage is low.

The adoption of crowdfunding activities in the higher education sector comes as a natural consequence of new public policies supported by a neo-liberal economic agenda that have been transforming universities - and other public systems - to become more market-oriented and dominated by corporate-minded logics (Broucker et al., 2018). To face increasing expenditures, universities need to complement their budgets with funding from other sources (Drezner $\&$ Huehls, 2015). The most prestigious universities obtain more funds due to their visibility not only through donations from alumni but also from wealthy donors wishing to acquire further legitimacy, visibility, and prestige (Bekkers \& Wiepking, 2011). These are research-based universities that can produce breakthrough research carrying the name of the donor associated 
with the research, leaving a long-lasting legacy (Worth et al., 2020). Less prestigious, teaching-oriented universities are not as appealing for potential outside donors, have less organizational experience and resources to arrange crowdfunding and other fundraising activities, and have a student population that tends to be less affluent, more diverse, and often made up of mature students with relatively low-paying jobs (Gearhart et al., 2019). These universities are often located in economically strained regions which thus undermine the most important factors predicting university donation: wealth, income, and social and economic status (Marr et al., 2005). In less prestigious, teaching-oriented universities, crowdfunding, and other fundraising activities may not be organizationally-led but rather driven by students and academics attempting to raise funds to face curricular limitations, support students, and enhance learning and teaching materials that their universities lack (Năstase, 2018). The ability to raise funds may also have implications within universities, prestigious or not, since some fields of knowledge such as the health sciences, engineering, and business schools are likely to benefit from the attention and support of donors compared with other fields of knowledge, because of their potential to visibly impact society (Nwakpuda, 2020). In this context, crowdfunding follows a systemic trend towards privatization in higher education but is also bound to reinforce inequalities across and within universities.

Crowdfunding follows a direct approach, is solely internet-based, tends to focus on broader audiences, requests relatively smaller contributions, and is increasingly a fundraising scheme sought by universities but mostly used by academics and students (Năstase, 2018). Contrary to the tenets of the theory of relationship marketing influencing traditional university fundraising, crowdfunding is essentially project-based, meaning that it has a stronger rationale towards raising funds focusing on time-constrained transactions than on establishing long-lasting and sustainable relationships (Jung \& Lee, 2019). As with other fundraising activities in higher education, crowdfunding is influenced by a commonality of interests (between the proponent and the funders) and a degree of emotional and identity attachment to the proposed projects (Cho et al., 2019). Within this framework, several universities have started to actively encourage their staff and students to engage in crowdfunding campaigns to support academic activities (Gearhard et al., 2018). A key motivator is that funding for higher education is unequally distributed, thus driving those receiving less funding to strive for additional resources (Colasanti et al., 2018). It is known that universities with resource scarcity devise many strategies to obtain further funding, such as specializing their offered programs, reducing tuition, or rebranding themselves to appear more attractive and competitive to potential students (Cattaneo et al., 2019). Another increasingly common strategy is to seek more donations from alumni and other potential donors, but this strategy is more frequently used in some countries than in others. More reputable (usually wealthier) universities obtain the most resources from these initiatives (Shaker \& Nathan, 2017). Other known strategies that academics pursue to attract funding in situations of scarcity tend to be associated with research activities and "citizen science" (Bonney et al., 2014). Invariably, during periods of public-funding scarcity, the greatest financial difficulties are faced by the less reputable universities and the students of bottom- and mid-table universities. These students also tend to be from lower- and mid-social strata and face problems of social inequality (Chou, 2015). Here, crowdfunding initiatives can emerge as promising tools, whereby students can access resources giving them agency in fostering their learning experiences at their current university. Eventually, these crowdfunding initiatives may promote equity in higher education settings (Llorente \& Morant, 2015).

Despite the potential benefits that crowdfunding offers, there are also several difficulties. In some cases, funding is allocated but the promised goal was subsequently not achieved or the proponent(s) failed to be accountable to their funders. This has led to calls for crowdfunding platforms to be regulated (Cummings et al., 2020). However, this problem is less common 
in academic-related crowdfunding activities, as these are largely donation-based crowdfunding platforms where people/agencies who fund projects voluntarily do not expect a tangible reward (Smith et al., 2015). Donors for these projects are often philanthropic and therefore different from traditional crowdfunding backers as the latter tends to regard rewards as key to their monetary participation (Gerber \& Hui, 2013). However, this lack of tangible rewards in scholarly and academic crowdfunding projects may also explain why proponents of these projects struggle to attract funding. Additionally, there is a concern that potential funders among the public may prefer less risky projects that are more likely to succeed or may not have the necessary knowledge to assess the quality and merit of projects for which funding is requested (Sturgis \& Allum, 2004). Indeed, successfully crowdfunded research projects are typically hosted on science-only crowdfunding platforms and their proponents include non-sciencerelated content to "sell" their project, rather than providing complex scientific explanations (Schafer et al., 2018). This "marketing" of the project and the need for universities to engage in sourcing funding directly from society underscores the entrepreneurial dimension of engaging in crowdfunding, which is well attuned to the transformation of HEIs into entrepreneurial organizations in this age of academic capitalism (Jessop, 2017).

\section{Data and method}

\section{Identifying crowdfunding in UK Universities}

Our data were collected from 1767 projects conducted from 2014 to 2018 which were funded via two major crowdfunding platforms, Hubbab and Justgiving. ${ }^{1}$ These projects involved 126 higher education institutions in the UK out of 133 institutions recognized at the end of 2018 by the UK government. Thus, we have a certain degree of confidence that our analysis of Hubbab and Justgiving is a valid analysis of the UK market for higher education crowdfunding. Hubbab, formerly known as Sponsorcraft, is a free-of-charge crowdfunding platform created for students. On this platform, the creator of a project must be a registered member of a university, college, or school. Staff can also create campaigns on Hubbab, although the project needs to directly benefit students. Justgiving, on the other hand, is a general crowdfunding platform for collecting charitable donations and charges a $5 \%$ fee for each donation through the site. On Justgiving, access is not restricted to higher education members, although university proponents can be easily identified in each proposal. Hence, all UK universities that we assessed are linked through their official website to either Hubbab or Justigiving; therefore, we relied on these two platforms to identify crowdfunding activities for higher education purposes in the UK.

On both platforms, fundraisers can create a profile and post a campaign to raise the desired funds. The campaign stays open for a limited time, typically 30-45 days. Platforms operate on an "all-or-nothing" mechanism: donors pledge an amount of money, and the donated funds are transferred to the campaign creators only if the predetermined funding goal is reached. Here, campaigns resemble the all-or-nothing nature of competitive grant proposals made to traditional funding agencies. There is no minimum donation amount.

\footnotetext{
1 There are other crowdfunding platforms for higher education. These platforms, however, either include HEIs alongside many other types of non-profit organizations or are focused on specific research programs. Hubbab and Justigiving are prominent crowdfunding platforms focused on higher education, according to the UK National Endowment for Science, Technology, and the Arts (https://media.nesta.org.uk/documents/ crowdfunding_good_causes-2016.pdf).
} 
Table 1 Summary of projects

\begin{tabular}{llll}
\hline No. of projects & Total & Justgiving & Hubbab \\
\hline $\begin{array}{l}\text { Total } \\
\text { Year }\end{array}$ & 1767 & 567 & 1200 \\
2014 & & & \\
2015 & 116 & 1 & 115 \\
2016 & 217 & 29 & 188 \\
2017 & 403 & 152 & 251 \\
2018 & 526 & 208 & 318 \\
Area & 505 & 177 & 328 \\
$\quad$ Student life & & & \\
Sustainability oriented & 152 & 18 & 486 \\
Creativity oriented & 540 & 48 & 134 \\
Technology transfer & 157 & 69 & 492 \\
\hline
\end{tabular}

This table presents a classification for all projects posted on Justgiving and Hubbab by staff and students in 133 UK universities over the periods 2014-2018. Classification of the 1767 projects by year and by topic, according to the labels provided by the platforms, are reported for the whole sample and each platform

\section{Crowdfunding projects}

Table 1 reports a summary of all projects posted on Justgiving and Hubbab by staff and students in 133 UK universities from 2014 to 2018. The upper panel reports the number of projects per year, showing how the phenomenon has grown over time, increasing from 116 proposals in 2014 to more than 500 in 2018, with a peak of 526 in 2017. Hubbab is the most popular although Justgiving showed a higher growth rate over the sampling period.

The lower panel reports a classification of projects into four categories based on civic crowdfunding literature (Stiver et al., 2015) and coded according to the labels provided by the two platforms. ${ }^{2}$ The first category (student life) includes projects to fund on-campus initiatives that provide courses and workshops to certain students (e.g. disabled students) enhance educational curriculums, pedagogical, and teaching activities, support university programs such as suicide-prevention, or direct funds to theatres or libraries. Second, we draw from Calic and Mosakowski (2016) identifying sustainability-oriented and creativity-oriented projects. The first focuses on environmental social causes that "sustain nature, life support systems, and community" (Calic \& Mosakowski, 2016, p.9), and are closely linked with experiential learning. Creative projects include films, video projects, and ideas for computer programs and relate to project-learning activities. Lastly, technology transfer campaigns aim to develop prototypes or testing capacities, which relate to experiential and project learning activities (Audretsch et al., 2016). Table 1 shows that the largest group of crowdfunding projects is related to student life (918 projects), while 540 proposals are creativity-oriented, and only 150 are sustainabilityoriented and dedicated to technology transfer. While both platforms host the four groups of projects, student life crowdfunding is particularly dominant in Justgiving.

\footnotetext{
${ }^{2}$ While the separate analysis of these groups would be of interest, it is out of the scope of our paper. Nevertheless, in "Results," among sensitivity analyses, we report an in-depth investigation of the specificities of student life projects.
} 


\section{Models and variables}

In our empirical analysis, we aim to identify institutional and context-specific variables correlated to the level of crowdfunding activity at each university in a year. Our analysis is based on 665 university-year observations (133 institutions, ${ }^{3}$ observed over 5 years, 2014-2018). There are three dependent variables in this analysis (Table 2). The first dependent variable is a "crowdfunding dummy," which identifies all institution-year observations wherein at least one project was launched. The second dependent variable is "crowdfunding activity," which identifies the diffusion of crowdfunding activities and is operationalized by the number of projects listed on each crowdfunding website per institution per year. The third dependent variable is "crowdfunding amount," which measures the financial relevance of such activity by the total amount of money raised. Given the binary nature of the first variable, a panel logit model is estimated when analyzing the presence of crowdfunding activity at each university. The second model, estimating the number of projects, is estimated through panel-negative binomial regressions. Last, the amount raised is analyzed using Cragg's double-hurdle model. This model is needed because the "crowdfunding amount" is observable only for university-year observations with at least one project. The double-hurdle model, originally proposed by Cragg (1971), assumes that two hurdles must be passed before a positive level of the dependent variable is observed. In our context, the first hurdle involves the initiation of crowdfunding activity in a certain institution (similar to what we analyze when looking at the first dependent variable), whereas the second hurdle concerns the number of creators who decided to propose projects. This model considers these features of our data by estimating a two-stage model wherein the first stage is equivalent to our "crowdfunding dummy analysis" and the second stage effectively analyzes the "crowdfunding amount." "We report estimates for these models both with fixed and random effect estimations. ${ }^{5}$

Concerning the independent variables (see Table 2), we leverage the literature on higher education engagement and social crowdfunding to identify a list of determinants that are likely to be correlated with the level of fundraising at each university. The determinants were classified into the following four groups: student variables, staff variables, financial variables, and regional variables. A control for the institution's size (number of students) is included in all specifications. Institutional data on students, staff, and finances were retrieved from UK Higher Education Statistics.

\footnotetext{
3 To avoid sample selection bias, universities with no crowdfunding activities (inactive universities) are also included in our analysis. Differences between active and inactive universities are analyzed in Table 3.

${ }^{4}$ Notice that in the double-hurdle models, unlike in the Heckman selection model wherein zeros are not affected by the second output (the second hurdle), zero crowdfunding is the result of no participation in crowdfunding or zero proposals in a university that might have participated in such activity in other periods. However, as in the Heckman models, it is a good practice to include identification conditions in the first stage. In our case, we include a parameter that sums the proposals in other UK universities in the same year.

5 Even though we include several institutional features in our regression, it is likely that unobservable university features affected our results, such that a fixed effect model is theoretically appropriate. At the same time, there are two important issues in using fixed effect models that we need to consider: first, our panel is featured by a short T (namely, by a small number of observations per unit); second, some of our independent variables show small variations over $\mathrm{T}$. Therefore, while including fixed effect may mitigate bias because of omitted variables, it could lead to losing information from our analysis. This is why we report in what follows both fixed and random effect estimations and discuss differences where needed.
} 
Table 2 Description of variables

Dependent variables

Crowdfunding dummy

Crowdfunding activity

Funds raised

Explanatory variables-student

State-school students

Low-participation neighborhoods

Female ratio

Part-time ratio

Non-UK ratio

Explanatory variables-staff

Staff-to-student ratio

Academic staff ratio

Full-time staff ratio

Female ratio

Non-white ratio

Average staff age

Explanatory variables-financials

Total income/student

Teaching income ratio

Surplus

Explanatory variables-region

GDP

Unemployment

Gini coefficients

Explanatory variables_controls

University size
Dummy variable, equal to 1 if the university i engaged in student crowdfunding activity in the year $\mathrm{j}$

Number of projects posted by students enrolled in the university i in the year $\mathrm{j}$

Natural logarithm of the amount raised by students enrolled in the university $i$ in the year $\mathrm{j}$ (in $\mathrm{m} f$ )

Percentage of students from state schools or colleges

Percentage of students from low-participation neighborhoods

Percentage of female students

Percentage of part-time students

Percentage of non-UK students

Number of total academic staff divided by the number of students

Number of total academic staff divided by the number of total staff

Number of full-time academic staff divided by the number of total academic staff

Number of female academic staff divided by the number of total academic staff

Number of non-white academic staff divided by the number of total academic staff

Average age of academic staff

Ratio of total income to the total number of enrolled students

Percentage of total income from teaching fees (i.e., tuition fees)

Surplus (or deficit) as a percentage of total income

Regional GDP per capita, calculated in the Nomenclature of Territorial Units for Statistics (NUTS2 region); values are corrected per inflation with CPI, with 2018 prices $=100$

Regional unemployment rate, calculated in the NUTS2 region

Gini coefficient, calculated in the NUTS2 region

Total number of students. In the regression analysis, natural logarithm of this value is employed

University student-body variables include a set of determinants related to socio-economic conditions that may cause students to be active in crowdfunding. The variables "state-school students" and "low-participation neighborhoods" are two variables about the social and economic class of the students that predict student enrolment but are also associated with the prestige and resources of universities. These variables complement one other because one is focused on the school dimension while the other on first- and close second-degree socialization (Culligan \& Duggan, 2016).

The State-school variable refers to pre-university education. In general, they are schools run and funded by the government (although the private sector has been participating in 


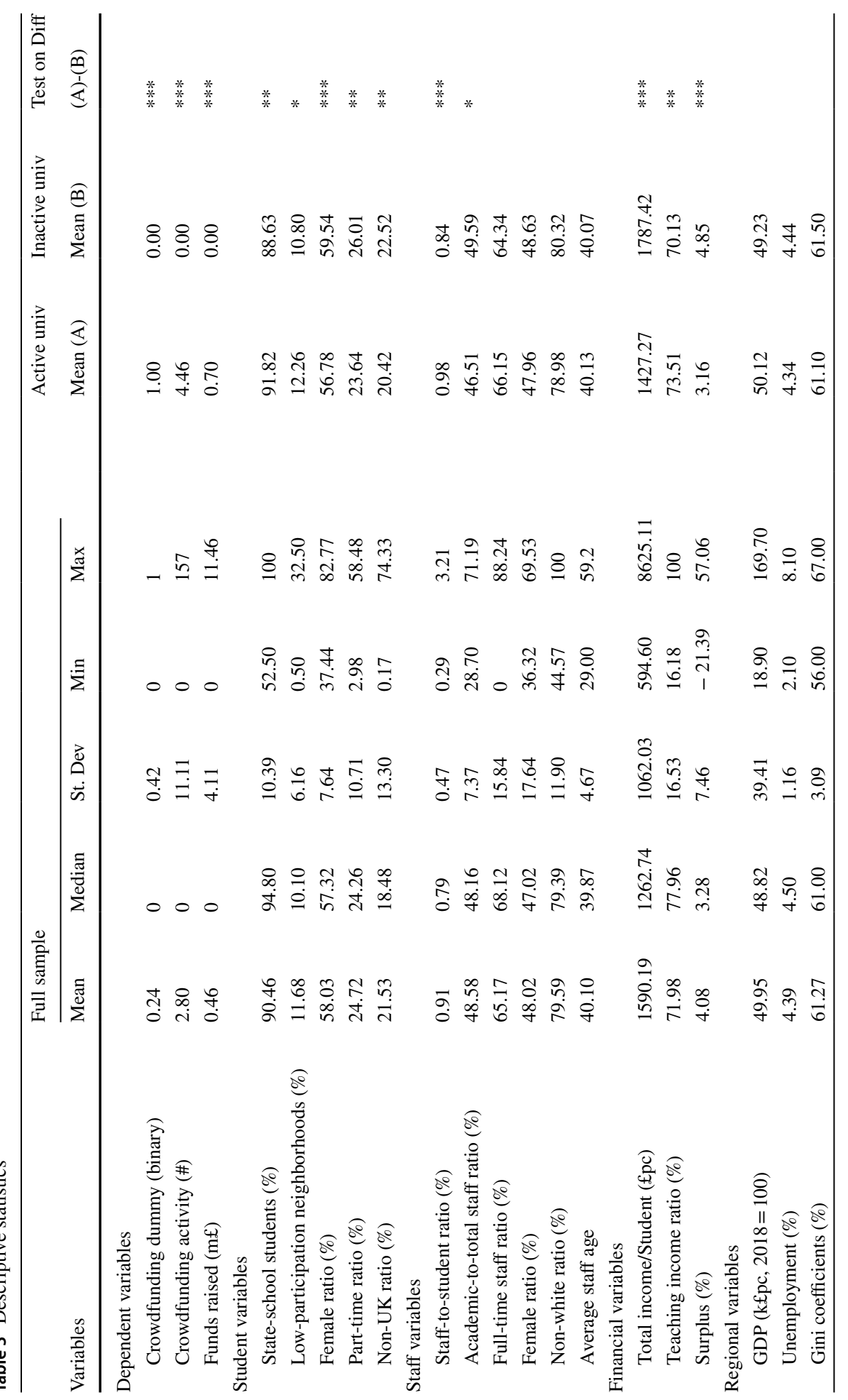




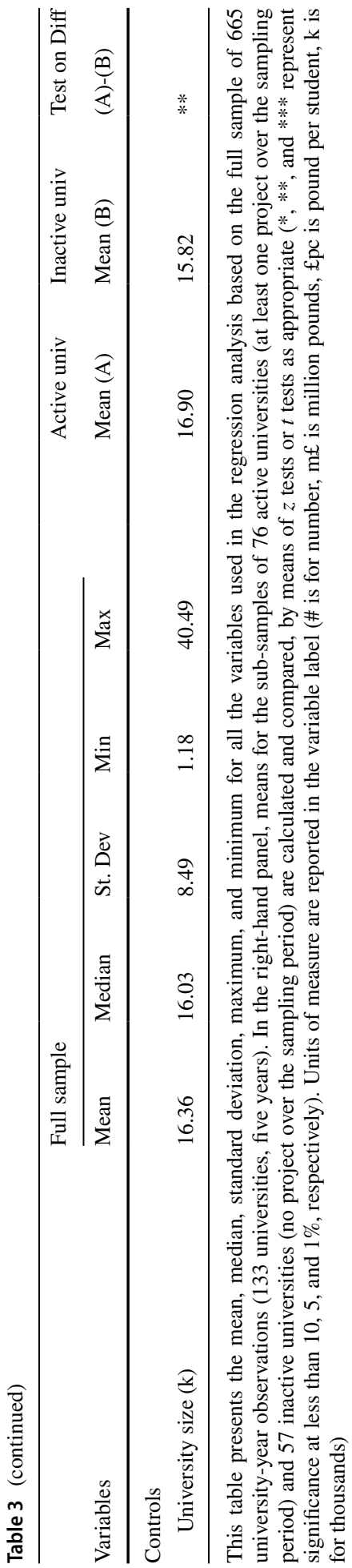


state schools in recent years). Although some state-schools are selective and have most of their students sent to universities, most state-schools are non-selective and only some of their students go to universities (Budd, 2017). By contrast, private schools (independent schools/public schools) charge tuition fees and are independent of many of the stateschool-regulations. Students who plan to go to university will take GCE A-levels, which are organized by exam boards, not universities. Students need to apply via the Universities and Colleges Admissions Service (UCAS) by mid-January to start university in October, even though they will not finish their GCE A-levels until May-June. So, students apply for multiple universities based on their anticipated grades. If they succeed in attaining the grades, then they get offers from universities and can choose where to go. If they underperform, there is a second chance called "clearing" where they can apply for different universities that may have places available. Generally, students can find a place, although some prefer to wait a year and re-take exams if they want to get into a higher-tier university. There are exceptions. Oxbridge students need to be interviewed in addition to sharing their academic qualifications and personal statement.

Most prestigious universities in the UK, besides being academically selective, are also socially selective and have a lower percentage of students from state schools and low-participation neighborhoods (Boliver, 2013). Those first in their family to attend university usually come from low socio-economic status families that are unable to prepare them for higher education or support them financially (Hunt et al., 2018). State-school students and those coming from low-participation neighborhoods overwhelmingly originate from working-class backgrounds, are more likely to study at local, less prestigious, teaching-oriented universities (Budd, 2017) and struggle to finance their studies while being concurrently debt averse (Callendar \& Jackson, 2005). Considering that personal income is a key driver to donate, one cannot expect universities with large proportions of students from state-schools and low-participation neighborhoods to derive substantial income from them. However, a student population with low resources may feel motivated to propose fundraising activities themselves (Năstase, 2018).

The variable "female ratio" is important because females are more prone to donate and be successful in crowdfunding activities than males (Greenberg \& Mollick, 2017). Parttime students tend to study academic courses that are vocationally-oriented and provided in teaching-oriented universities. Often, they are mature students obtaining qualifications to further their careers and, because of their study-type and professional life constraints, they are less emotionally engaged with the university. These characteristics make them less likely to donate to the university (Gearhart et al., 2019) but also mean that they participate less in crowdfunding activities. Conversely, "non-UK ratio" (the percentage of nonUK students) refers to students whose families can afford for them to study abroad and at universities that tend to be prestigious and not lacking in research and teaching resources (Prazeres, 2019).

Qualitative studies on crowdfunding engagement have shown that a lack of educational resources may lead students and academics to engage in crowdfunding (Năstase, 2018). Thus, it was essential for us to control for two major types of university educational resources because they indicate the extent of the resources that academics and students can access: human resources (such as academic and nonacademic staff) and financial resources. The former includes the "staff-to-student ratio," "academic staff ratio," and "full-time staff ratio" that are known to differ significantly between teaching- and research-oriented universities (Luque-Martinez \& Faraoni, 2020). These variables also indicate time availability that academics can 
dedicate to teaching and supporting students (Coates, 2016). As above, the "female staff ratio" is also significant as females are more successful in crowdfunding activities than males (Greenberg \& Mollick, 2017) and it is expected that universities with more female academics may have greater engagement and success through crowdfunding. The "non-white ratio" matters for two reasons: less prestigious, teaching-oriented universities have greater proportions of non-white academics (Gearhart et al., 2019) and race is known to affect crowdfunding success (Younkin \& Kuppuswamy, 2018). Financial resources outline another dimension of educational resources through three variables. "Total income/student" proxies the amount of funding per student, and therefore, the availability of resources that academic staff and students have for curricular and learning activities. Fewer resources may lead students and academics to search for additional income/funding through crowdfunding. "Teaching income ratio" indicates the university's reliance on tuition paid by students. Here, a more exposed financial position incentivizes universities to diversify their income streams and crowdfunding becomes a viable option (Garland, 2020). "Surplus" indicates the wealth of a university which is important in fundraising activities because successful fundraising activities need investment and high-cost professionals to advise funding strategies and activities (Sargeant \& Jay, 2014). This is critical in an era of institutional self-promotion, but "surplus" may also lead some universities to engage less in fundraising activities because they have a "financial cushion" (Parker, 2013).

Last, regional variables are used in our analysis for three reasons. Firstly, most universities' student bodies are from the surrounding region, particularly in teaching-oriented universities (Cattaneo et al., 2019). Secondly, students from lower social strata tend to enroll in nearby universities even if they can attend other universities because of educationrelated costs (Sá et al., 2012). Thirdly, universities contribute to local communities but also obtain resources from them. So, universities located in wealthier and stable social-cultural regions can access more resources for learning activities (Charles, 2003). Relevant literature highlights the importance of the region when considering fundraising activities led by universities (Drezner \& Huehls, 2015). The regional variables in the analyses include regional GDP per capita, regional unemployment, and Gini coefficients. These data were collected from Eurostat.

Table 3 provides descriptive statistics. In our sample, at least one project was posted in $24 \%$ of the university-year observations, with an average of 2.8 projects created and approximately $£ 460,000$ raised per university per year. Universities in our sample enroll more than $90 \%$ of students from state schools or colleges and less than $12 \%$ of students from low-participation neighborhoods. Staff statistics show that more than $20 \%$ of employees are non-white and the average employee age is just over 40 years. More than $70 \%$ of funds are from teaching income (i.e., tuition fees), and the average university has a $4 \%$ annual surplus.

In the right-hand panel of Table 3, we report first evidence on the difference between the 76 universities with at least one project over the sampling period (active universities) and the 57 universities with no projects (inactive universities). Statistics for the two subsamples are reported, as well as $z$ tests for the difference of proportions and $t$ tests for the difference of means. These differences allow the identification of specifics within universities with crowdfunding initiatives. They are characterized by a larger share of stateschool students, a larger share of low-participation neighborhoods, a lower female ratio, a lower part-time ratio, and a lower non-UK ratio. A higher staff-to-student ratio and lower academic-to-total staff ratio is correlated with higher participation. Active universities are characterized by lower total income per student, higher teaching income ratios, and a lower 
annual surplus. We do not find statistical differences in regional variables, while larger universities are more likely to be active. Most of these preliminary findings are confirmed in Table A1 (appendix), reporting correlation coefficients. ${ }^{6}$ Indeed, several of these features are likely to overlap, and a better assessment would be provided in a multivariate setting.

\section{Results}

Table 4 reports our econometric analysis results. Model (1) is a fixed-effect panel logit model on the probability that at least one crowdfunding project was created in a certain university in a year, model (2) is a fixed-effect panel negative binomial regression on the number of projects per year, and model (3) is a Cragg's double-hurdle model on the amount raised through student crowdfunding activity per year, where both models are estimated with fixed effects. The three models provide a thought-provoking portrait of the determinants of crowdfunding activities in the UK higher education system, with a focus on the effects of student, staff, financial, and regional variables. Models (4-6) are replicated in a random-effect setting. ${ }^{7}$ Given that the Hausman tests support the choice of fixed-effect models in all instances, ${ }^{8}$ we will mainly discuss the implications of the results of fixedeffect models, highlighting, where necessary, the differences according to the randomeffect estimation. ${ }^{9}$

With respect to student variables, the coefficients in Model $1(0.022, p<0.01)$ and Model $2(0.016, p<0.05)$ show that the presence of students from state schools is positively correlated both with the presence and intensity of crowdfunding activity. A slight, but still significant coefficient for students from low-participation neighborhoods $(0.042$, $p<0.10)$ further confirms that students from non-wealthy areas are positively correlated to the intensity of crowdfunding activity. These results suggest that students from families with a lower social and economic status tend to enroll in less prestigious universities where participation and engagement in crowdfunding activities dominate. The presence of

\footnotetext{
6 A few high values in the correlation matrix may raise concerns of multicollinearity. We estimated the Variance Inflation Factor, identifying a highest value of 6.64, and an average value of 2.31, below the levels of 10 and 2.5 that are considered as critical in applied econometric literature (see Giacalone et al., 2018). Given the nature of our study, where we look at determinants of crowdfunding activity without proposing a causal model, we find it important to keep the number of controls large, in order to take into account the role of all features describing a higher education system. We also replicated our analysis when excluding one of the variables with the highest correlation value (total income per student) yielding qualitatively equivalent results.

7 Given that all our models are estimated through Maximum Likelihood estimators, quality of fit is reflected in the log-likelihood value. In order to provide evidence on the quality of fit we also estimated McFadden's pseudo $R^{2}$ (McFadden, 1984). Similar to $R^{2}$, pseudo $R^{2}$ is theoretically bounded between 0 and 1 and provides evidence for a better fit the closer it is to 1 . However, this value is not to be interpreted as a percentage of explaine variance, and its empirical value is generally much lower than what traditionally expected when analyzing $R^{2}$.

8 We ran Hausman tests on the null hypothesis that the preferred model is the random effect vs. the alternative fixed effect, and we found that a fixed-effect model is appropriate in all instances. Null hypotheses are rejected at less than $5 \%$ significance in all cases.

9 Our panel data is characterized by a relatively large $\mathrm{N}$, the number of institutions (133), and a small value for $\mathrm{T}$, the number of periods (5). This might create concerns in dynamic panel modeling, which reach consistence for large values of $\mathrm{T}$, though this concern is, in our view, mitigated for our model due to the qualitative nature of our main dependent variables (with the exception of model 3, where raised funds, though, are observable only when crowdfunding activity is present).
} 


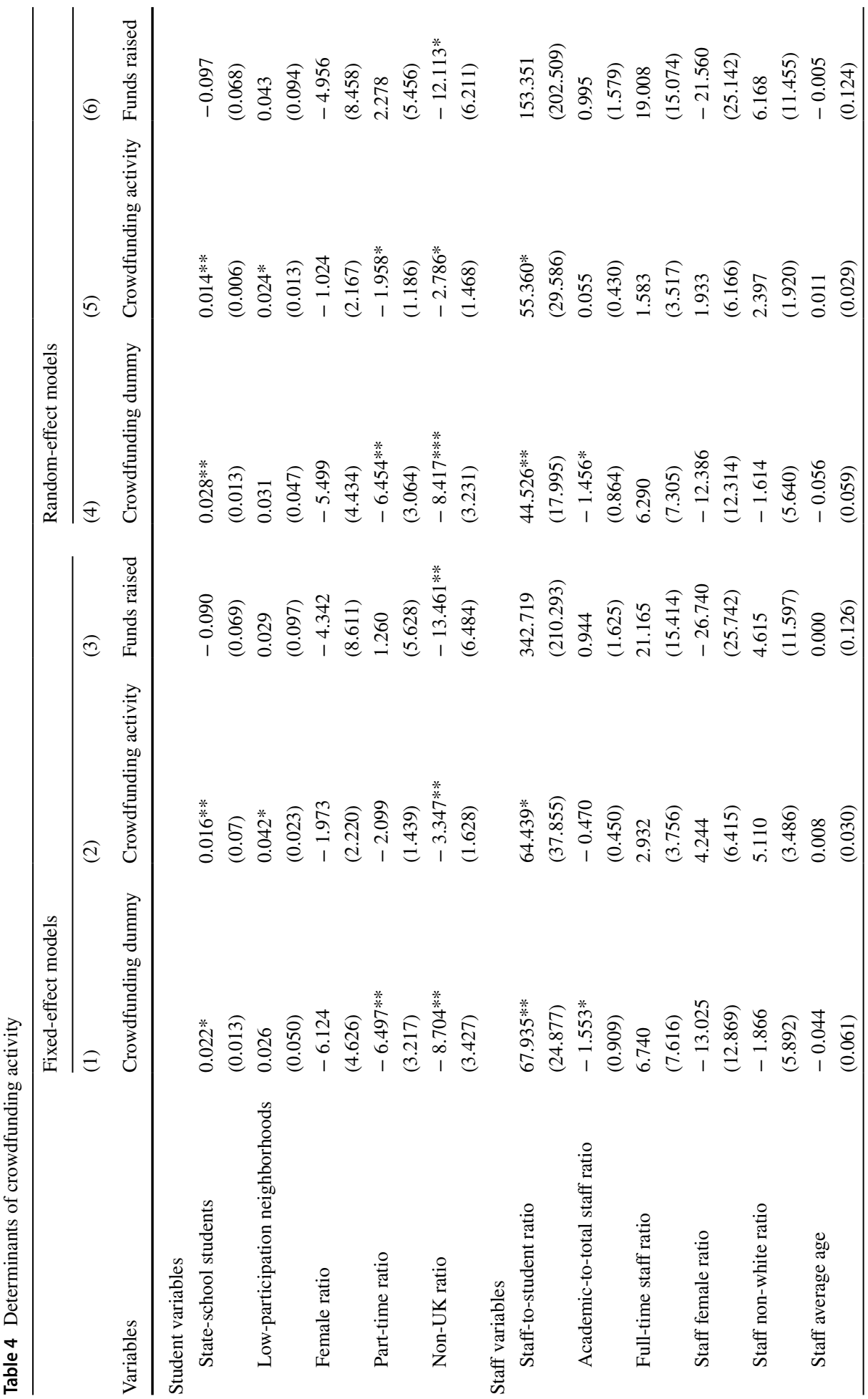




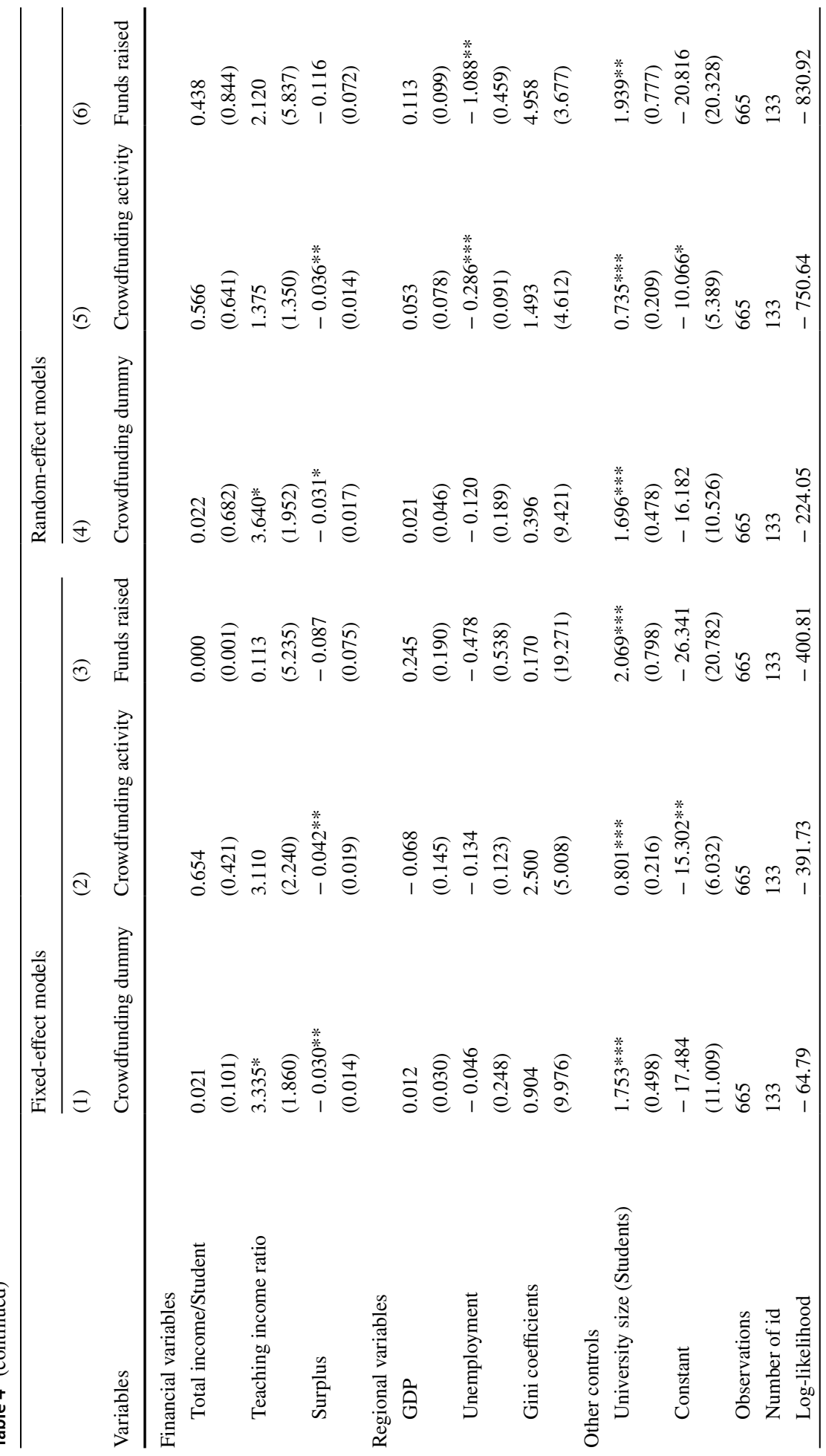




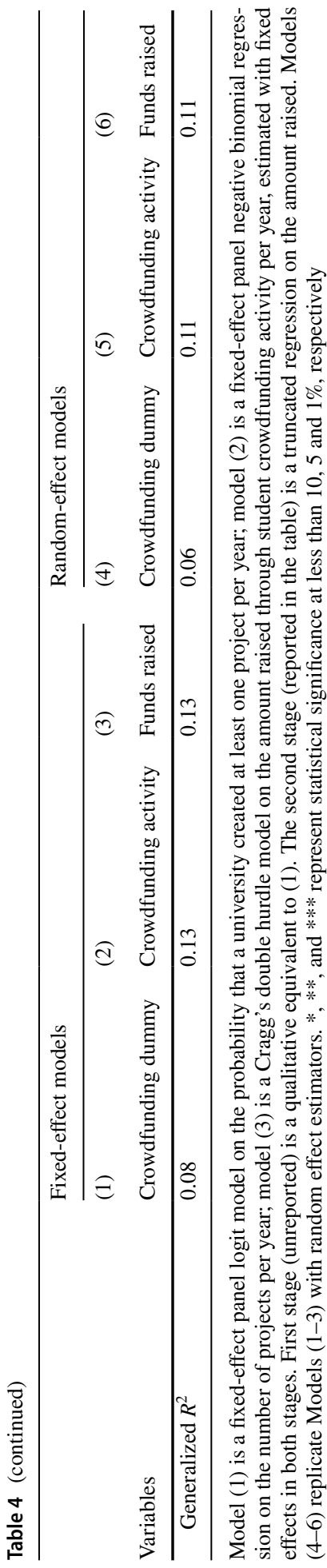


state-school students increases the likelihood of participation in crowdfunding activities by $16 \% .{ }^{10}$ When considering the number of crowdfunding projects submitted for funding (i.e., engagement), we find an increase of $14 \%^{11}$ and $22 \%$ due to the proportion of students from state schools and low-participation neighborhoods respectively. This finding suggests that social and economic status gaps in the student body of a university are predictors of participation and engagement in crowdfunding. No significant effect is found for the femaleto-male composition of the student bodies.

The finding that universities with a higher proportion of non-UK students are negatively correlated with crowdfunding projects further emphasizes that crowdfunding is an activity typically engaged in by less prestigious universities in the UK higher education system (the internationalization of higher education is still mostly participated in by overseas students from high and upper-middle socioeconomic classes, who tend to enroll in reputable universities; Prazeres, 2019). Universities with a higher percentage of non-UK students participate $12 \%$ less in crowdfunding, submit $14 \%$ fewer crowdfunding projects and raise $345 \%{ }^{12}$ less funding from crowdfunding projects. Further, our findings indicate that there may be a differentiation either within less prestigious universities or among the student populations in the less-reputable universities that also tend to be those enrolling higher percentages of part-time students. The fraction of part-time students is negatively correlated to crowdfunding activity (by 7\%) and to the number of projects (by 6\%). However, this result is only significant according to the random effect estimation (Model 5). This finding shows that even if crowdfunding is a way to access funding, it may not equally benefit all students from lower socio-economic backgrounds. Students who benefit less may include part-time students who, due to prioritizing family commitments and income opportunities, may not have the time and energy to engage in additional activities (McLinden, 2017).

Our findings also underline the importance of higher academic staff-to-student ratios for both participation and engagement in crowdfunding. The results show that a higher academic staff-to-student ratio increases the likelihood of at least one project being created (by 22\%) and the expected number of projects (by 18\%). Higher academic staff-to-student ratios reflect the key role that academics play in supporting or leading learning activities that can benefit their students, particularly when staff adopt a project-based learning structure aligned with crowdfunding projects (Bernal, 2016). However, in this process, non-academic staff also play a relevant role in promoting the participation of students and academics in crowdfunding projects. Thus, the results suggest that when academics have more non-academic staff support, the likelihood that a project is activated increases substantially. In particular, with an increase in the academic-to-non-academic staff ratio, the likelihood that a crowdfunding project is

\footnotetext{
10 This is a marginal percentage increase in participation probability with respect to the mean value, calculated from Table 3, model 1, by increasing the variable of interest by one standard deviation and setting all of the other variables at their means and the dummy variables at their median state.

11 This is a marginal percentage increase in the number of projects concerning the mean value, calculated from Table 3, model 2, by increasing the variable of interest by one standard deviation and setting all of the other variables at their means and the dummy variables at their median state.

12 The marginal percentage increase in the funds raised, with respect to the mean value, was calculated from Table 3, model 3, when increasing the variable of interest by one standard deviation and setting all other variables at their means and the dummy variables at their median state.
} 
proposed decreases by $4 \%$. This indicates that having a larger number of non-academic staff may be important for the success of all academics-led scholarly activities. However, having greater numbers of both academic and non-academic staff may be challenging for less prestigious, teaching-oriented universities, where students with lower socio-economic backgrounds tend to enroll, as they face greater financial difficulties. The need for more academic staff may eventually be mitigated by these universities hiring more part-time academic staff, as there is no statistically significant difference in terms of participation, engagement, and resources derived from crowdfunding between full- and part-time staff. However, the hiring of part-time staff may increase the precarity of the academic profession in the UK (Kinman, 2016). Finally, the age and sex ratio of the staff body do not seem to play a role in participation, engagement, and revenue obtained from crowdfunding.

Our results confirm the challenging scenario of having greater numbers of academic and non-academic staff in less prestigious universities, by showing that universities with higher teaching income (teaching-oriented universities) and those with a deficit (a negative surplus) are more likely to engage in crowdfunding initiatives. This study shows that although the likelihood that less prestigious universities participate in crowdfunding activities increases by $6 \%$ when the teaching income ratio increases, the proceeds obtained from crowdfunding are not different from those obtained by other universities, including more research-intensive universities. This suggests that even universities that participate less in crowdfunding can derive similar amounts of funding from crowdfunding activities. These findings are also applicable to universities running a deficit as their student body is more likely to participate in crowdfunding (by 12\%) and have a greater number of crowdfunding projects (by 10\%). This may be because these universities generate conditions that require the students to be active in direct crowdfunding initiatives, or because the students feel the need to raise funding for their learning activities and experiences that they know they will not be able to obtain from their resource-poor universities.

The regional variables are largely not relevant. As an exception, the level of regional unemployment is significant in our random-effect specification, decreasing the likelihood of students engaging in crowdfunding projects (i.e., number of crowdfunding projects submitted). This lack of an effect of regional variables highlights the fact that crowdfunding has a national and international fundraising scope and is not regiondependent (Franzoni \& Sauermann, 2014).

In Table 5, we report the results of two sensitivity analyses, where we try to corroborate our results when taking into account project and platform specificities. Table 1 shows how projects are diversified in terms of objectives. Given that our dependent variables in the main analyses do not take into account for such differentiation, we report here (Models 1-3) the results when crowdfunding dummy, crowdfunding activity, and funds raised are calculated only according to student life projects, the largest group, and thus possibly the most appropriate to validate our arguments on student intensity and engagement. The results show that most of our 


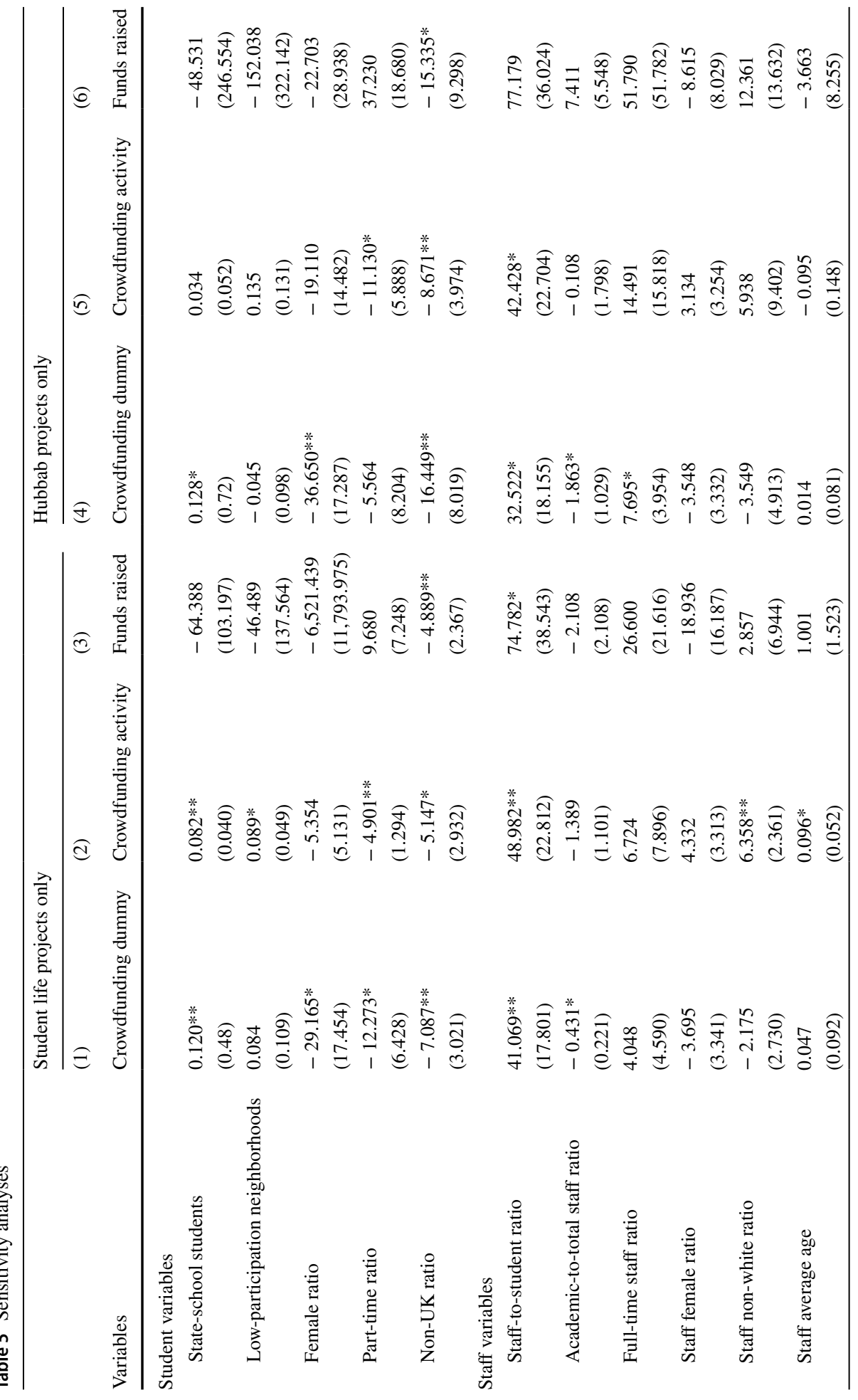




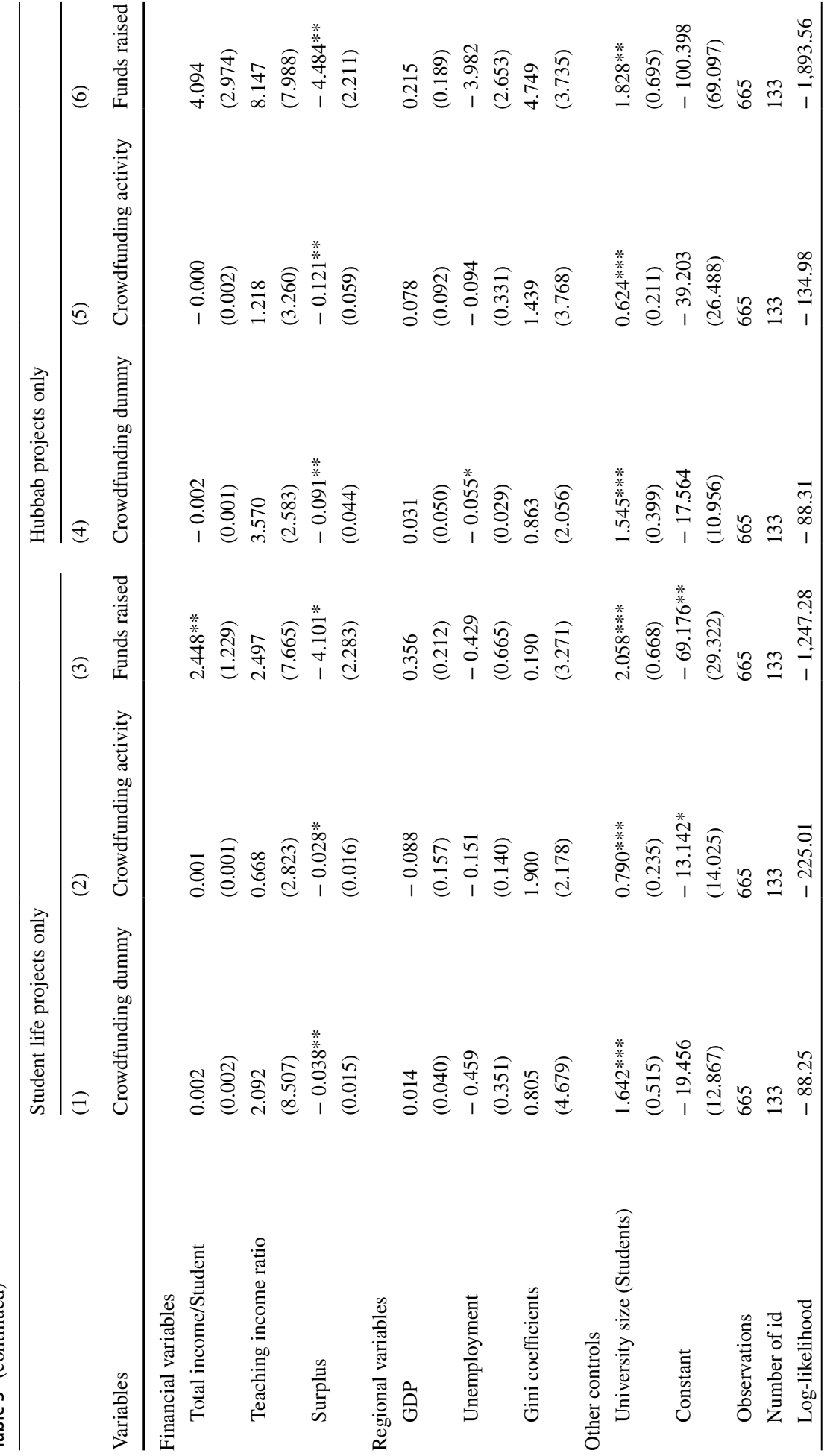




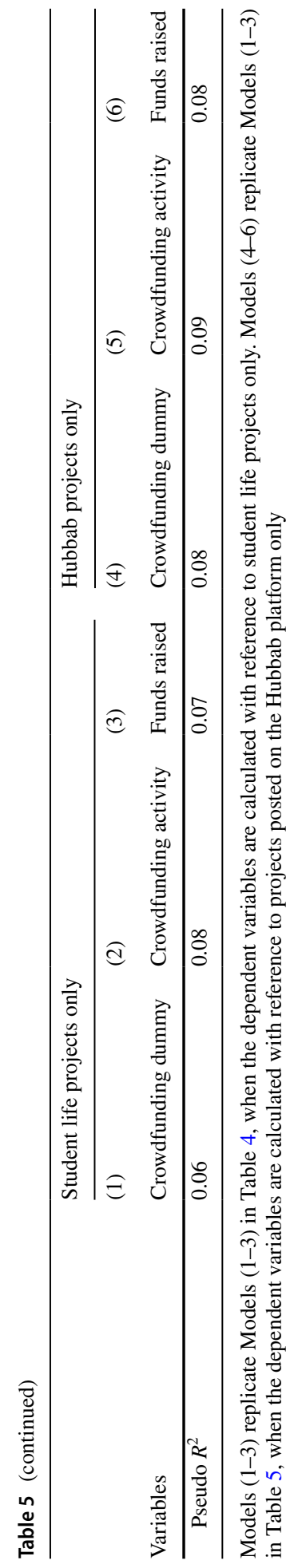


arguments are confirmed, and those related to student compositions are validated with higher levels of significance.

Another potential source of bias in our analysis is the fact that we collected information from two platforms. To assess whether the two platforms are characterized by different dynamics, we report results (Models 4-6) obtained when considering only projects posted in Hubbab, the larger of the two platforms. Results confirm most of our findings, in a few cases at a lower level of significance, possibly because of the smaller sample observed or the higher differentiation in projects posted on this platform.

\section{Conclusions}

Our findings place crowdfunding within the processes of marketization and privatization of higher education, largely in terms of the transfer of the costs for supporting learning activities in higher education settings from the state to interested communities. This finding is consistent with the major trends of privatization observed in mass and universal higher education systems (Teixeira \& Landoni, 2017). Crowdfunding is a form of financing in the wake of traditional fundraising activities that universities have been pursuing in developed countries with different success rates, but differs from the traditional fundraising activities because crowdfunding is decentralized. Academics and students are given the autonomy to engage in crowdfunding, and university management often supports this engagement, because it increases the university support base of donors, portraits the universities as innovative and entrepreneurial, and mitigates resource flaws. Examples of these rationales can be found in statements such as these: "crowdfunding has widened our supporter base, including young alumni. In fact, we have the highest proportion of alumni donors aged under 30 of any UK university. We couldn't have done this without our crowdfunding programme" (the Young Alumni Officer at the University of York), and "we'd never done anything like this before but welcomed the opportunity as a way of trying something new that could more closely connect our US and overseas donors with giving to the College" (the Director of Development, Alumni Relations, and Fellow at the Worcester College).

The findings suggest the use of crowdfunding as a strategy to obtain resources for some universities, enabling them to offer learning experiences as per the needs of the students and the perceived demands of the labor market and societies (Jung, 2020). We propose two possible explanations, both of which may apply but this could only be confirmed by expanding the research with qualitative methods, something that we leave for future research. First, crowdfunding is being used to supplement and/or complement resources to meet the learning experiences of students from universities that lack the resources to provide these experiences (Brooks, 2018). An alternative explanation is that crowdfunding is mostly used by students (and academic staff) to create a learning experience that they perceive to be more beneficial, but which their universities may not provide because they follow traditional teaching- and curricular-based thinking. If the latter is true, the results likely provide additional evidence 
of the democratization effect of digital finance, supporting Cumming et al.'s (2019) findings concerning stakeholder participation in equity firms. However, our findings seem to strongly support the former explanation, as crowdfunding participation and engagement are mostly sought by universities that are teaching-oriented, less prestigious, and have more students from state schools and low-participation neighborhoods. These universities lack adequate resources to provide comprehensive learning experiences, thus driving students (supported by academic and non-academic staff) to find other income sources for learning experiences that students feel are vital in tertiary education settings. In this process, some of these universities with a greater proportion of students from lower social and economic backgrounds may be at a greater disadvantage than others, because they may already face financial constraints that prevent them from hiring more academic and non-academic staff, which, as per our results, are critical factors in promoting the participation and engagement of students in crowdfunding projects. This finding underlines the importance of crowdfunding as an approach to gain resources that otherwise would be unobtainable, but at the same time raises doubts about whether crowdfunding can become a long-term, sustainable form of fundraising in environments with increasingly less public funding or for universities that predominantly enroll students from low socio-economic backgrounds. Finally, crowdfunding may be an effective way to obtain funding in countries like the USA and the UK, which have established cultures of philanthropy and alumni donations, but this may not be a feasible strategy in countries with different cultural mindsets, lesser wealth, and greater reliance on other funding sources (see Francioni et al., 2020).

\section{Appendix}

\section{Table A1 Correlation matrix}

This table presents the correlation coefficients among all variables employed in the regression analysis based on the full sample of 665 university-year observations (133 universities, five years). Coefficients in italics represent coefficients statistically different from zero at less than $1 \%$ significance. 


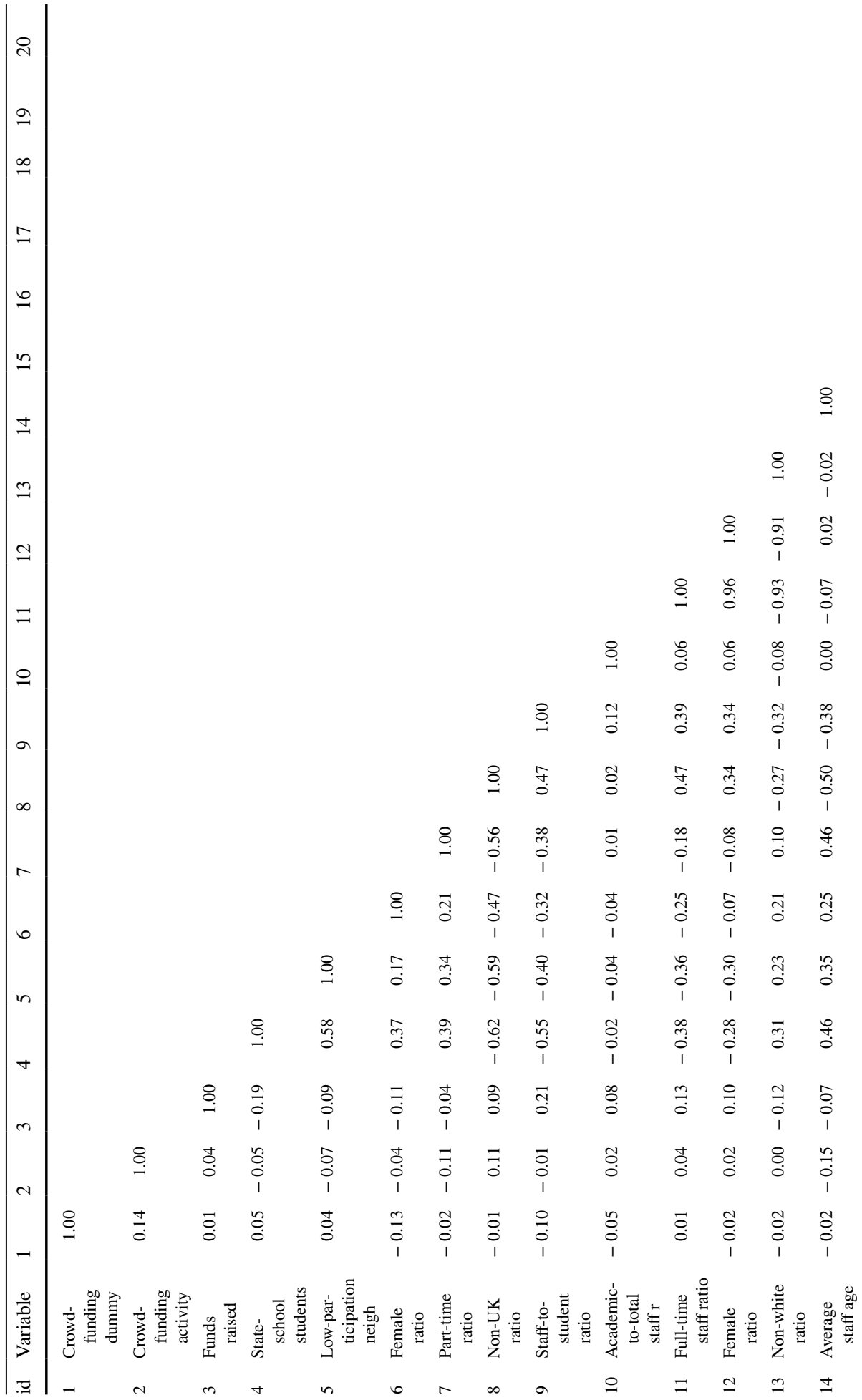




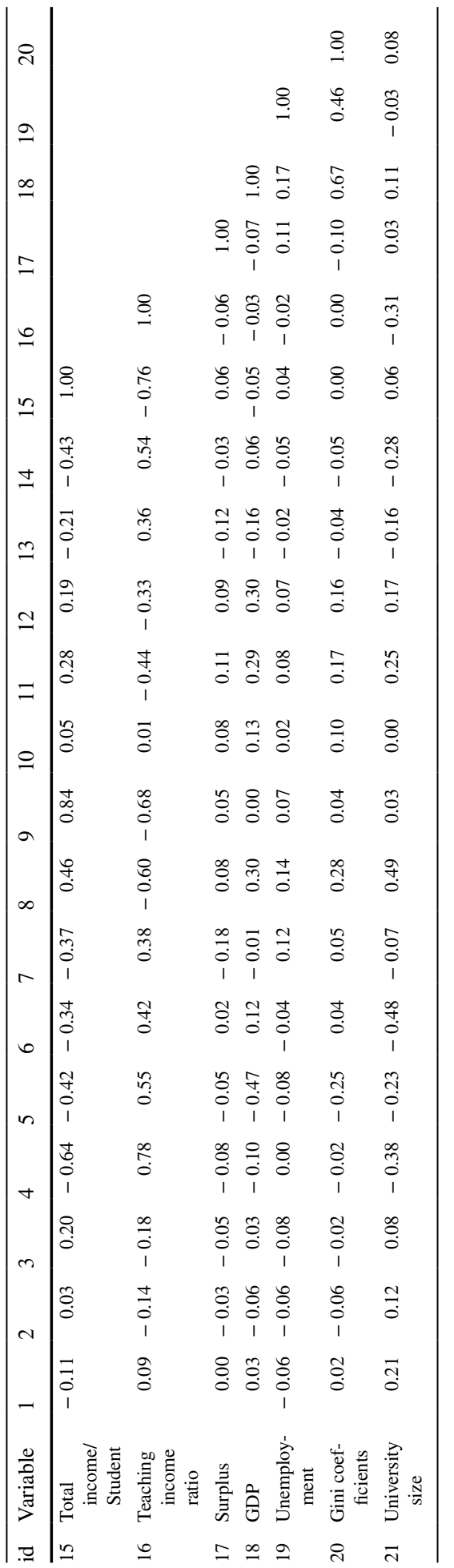


Funding Open access funding provided by Università degli Studi di Bergamo within the CRUI-CARE Agreement.

Open Access This article is licensed under a Creative Commons Attribution 4.0 International License, which permits use, sharing, adaptation, distribution and reproduction in any medium or format, as long as you give appropriate credit to the original author(s) and the source, provide a link to the Creative Commons licence, and indicate if changes were made. The images or other third party material in this article are included in the article's Creative Commons licence, unless indicated otherwise in a credit line to the material. If material is not included in the article's Creative Commons licence and your intended use is not permitted by statutory regulation or exceeds the permitted use, you will need to obtain permission directly from the copyright holder. To view a copy of this licence, visit http://creativecommons.org/licenses/by/4.0/.

\section{References}

Antonenko, P. D., Lee, B. R., \& Kleinheksel, A. J. (2014). Trends in the crowdfunding of educational technology startups. TechTrends, 58(6), 36-41.

Audretsch, D. B., Lehmann, E. E., Paleari, S., \& Vismara, S. (2016). Entrepreneurial finance and technology transfer. Journal of Technology Transfer, 41, 1-9.

Bassani, G., Marinelli, N., \& Vismara, S. (2019). Crowdfunding in healthcare. Journal of Technology Transfer, 44(4), 1290-1310.

Bekkers, R., \& Wiepking, P. (2011). A literature review of empirical studies of philanthropy: eight mechanisms that drive charitable giving. Nonprofit and Voluntary Sector Quarterly, 40(5), 924-973.

Bernal, C. M. R. (2016). Student-centred strategies to integrate theoretical knowledge into project development within architectural technology lecture-based modules. Architectural Engineering and Design Management, 13(3), 223-242.

Block, J., Colombo, M., Cumming, D., \& Vismara, S. (2018). New players in entrepreneurial finance and why they are there. Small Business Economics, 50, 239-250.

Boliver, V. (2013). How fair is access to more prestigious UK universities? British Journal of Sociology, 64(2), 244-364.

Bonney, R., Shirk, J. L., Phillips, T. B., Wiggins, A., Ballard, H. L., Miller-Rushing, A. J., \& Parrish, J. K. (2014). Next steps for Citizen Science. Science, 343(6178), 1436-1437.

Brooks, R. (2018). Understanding the higher education student in Europe: a comparative analysis. Compare, 48(4), 500-517.

Broucker, B., De Wit, K., \& Verhoeven, J. C. (2018). Higher education for public value: taking the debate beyond new public management. Higher Education Research and Development, 37(2), 227-240.

Budd, R. (2017). Disadvantaged by degrees? How widening participation students are not only hindered in accessing HE, but also during - and after - university. Perspectives: Policy and Practice in Higher Education, 21(23), 111-116.

Calic, G., \& Mosakowski, E. (2016). Kicking off social entrepreneurship: how a sustainability orientation influences crowdfunding success. Journal of Management Studies, 53(5), 738-767.

Callendar, C., \& Jackson, J. (2005). Does the fear of debt deter students from higher education? Journal of Social Policy, 34(4), 509-540

Capano, G., \& Pritoni, A. (2020). What really happens in higher education governance? Trajectories of adopted policy instruments in higher education over time in 16 European countries. Higher Education, 80, 989-1010.

Cattaneo, M., Horta, H., Malighetti, P., Meoli, M., \& Paleari, S. (2019). Universities' attractiveness to students: the Darwinism effect. Higher Education Quarterly, 73(1), 85-99.

Charles, D. (2003). Universities and territorial development: reshaping the regional role of UK universities. Local Economy, 18(1), 7-20.

Cho, M., Lemon, L. L., Levenshus, A. B., \& Childers, C. C. (2019). Current students as university donors?: determinants in college students' intentions to donate and share information about university crowdfunding efforts. International Review on Public and Nonprofit Marketing, 16(1), 23-41.

Chou, C. P. (2015). Who benefits from Taiwan's mass higher education? In J. C. Shin, G. A. Postiglione, \& F. Huang (Eds.), Mass Higher Education Development in East Asia (pp. 89-103). Singapore: Springer.

Coates, H. (2016). Assessing student learning outcomes internationally: insights and frontiers. Assessment \& Evaluation in Higher Education, 41(5), 662-676.

Colasanti, N., Frondizi, R., \& Meneguzzo, M. (2018). Higher education and stakeholders' donations: successful civic crowdfunding in an Italian university. Public Money \& Management, 38(4), 281-288. 
Cragg, J. G. (1971). Some statistical models for limited dependent variables with application to the demand for durable goods. Econometrica (pre-1986), 39(5), 829.

Culligan, J., \& Duggan, J. (2016). A school-level gravity model of student migration flows to higher education institutions. Spatial Economic Analysis, 11(3), 294-314.

Cumming, D., Meoli, M., \& Vismara, S. (2019). Does equity crowdfunding democratize entrepreneurial finance? Small Business Economics, forthcoming. https://doi.org/10.1007/s11187-019-00188-z.

Cummings, M. E., Rawhouser, H., Vismara, S., \& Hamilton, E. L. (2020). An equity crowdfunding research agenda: evidence from stakeholder participation in the rulemaking process. Small Business Economics, 54, 907-932.

Drezner, N. D., \& Huehls, F. (2015). Fundraising and institutional advancement. New York: Routledge.

Ferlie, E., Musselin, C., \& Andresani, G. (2008). The steering of higher education systems: a public management perspective. Higher Education, 56(3), 325-348.

Francioni, B., Curina, I., Dennis, C., Papagiannidis, S., Alamanos, E., Bourlakis, M., \& Hegner, S. M. (2020). Does trust play a role when it comes to donations? A comparison of Italian and US higher education institutions: Higher Education. https://doi.org/10.1007/s10734-020-00623-1.

Franzoni, C., \& Sauermann, H. (2014). Crowd science: the organization of scientific research in open collaborative projects. Research Policy, 43(1), 1-20.

Garland, M. (2020). How vulnerable are you? Assessing the financial health of England's universities. Perspectives: Policy and practice in Higher Education, 24(2), 43-52.

Gearhard, G. D., Smith, E. A., \& Miller, M. T. (2018). Community college crowdfunding: new strategy or latest fad? Community College Journal, 1-4.

Gearhart, G. D., Smith, E. A., \& Miller, M. T. (2019). Community college crowdfunding: new strategy or latest fad? Community College Journal of Research and Practice, 43(9), 618-621

Gerber, E. M., \& Hui, J. (2013). Crowdfunding: motivations and deterrents for participation. ACM Transactions on Computer-Human Interaction 20(6), Article 34.

Giacalone, M., Panarello, D., \& Mattera, R. (2018). Multicollinearity in regression: an efficiency comparison between L p-norm and least squares estimators. Quality \& Quantity, 52(4), 1831-1859.

Greenberg, J., \& Mollick, E. (2017). Activist choice homophily and the crowdfunding of female founders. Administrative Science Quarterly, 62(2), 341-374.

Holmwood, J., \& Servós, C. M. (2019). Challenges to public universities: digitilisation, commodification and precarity. Social Epistemology, 33(4), 309-320.

Hunt, C., Collins, B., Wardrop, A., Hutchings, M., Healslip, V., \& Pritchard, C. (2018). First- and second-generation design and engineering students: experience, attainment and factors influencing them to attend university. Higher Education Research and Development, 37(1), 30-43.

Jessop, B. (2017). Varieties of academic capitalism and entrepreneurial universities. Higher Education, 73(6), 853-870.

Jongbloed, B., \& Vossensteyn, H. (2016). University funding and student funding: international comparisons. Oxford Review of Economic Policy, 32(4), 576-595.

Jung, J. (2020). The fourth industrial revolution, knowledge production and higher education in South Korea. Journal of Higher Education Policy and Management, 42(2), 134-156.

Jung, Y., \& Lee, M.-Y. (2019). Exploring departmental-level fundraising: relationship-based factors affecting giving attention in arts higher education. International Journal of Higher education, 8(3), 235-246.

Kinman, G. (2016). Effort-reward imbalance and overcommitment in UK academics: implications for mental health, satisfaction and retention. Journal of Higher Education Policy and Management, 38(5), 504-518.

Langa, P. (2017). A disjointed multi-campus system: the neo-liberal expansion and fragmentation of Mozambican higher education. Tertiary Education and Management, 23(1), 23-40.

Law, W. W. (2019). Politics, managerialism, and university governance: lessons from Hong Kong under China's rule since 1997. Singapore: Springer.

Lepori, B., \& Jongbloed, B. (2018). National Resource allocation decisions in higher education: objectives and dilemmas. In B. Cantwell, H. Coates, \& R. King (Eds.), Handbook on the politics of higher education (pp. 211-228). Cheltenham: Edward Elgar.

Llorente, R., \& Morant, M. (2015). Crowdsourcing in higher education. In F. J. Garrigos-Simon, I. Gil-Pechuán, \& S. Estelles-Miguel (Eds.), Advances in Crowdsourcing (pp. 87-95). Dordrecht: Springer.

Luque-Martínez, T., \& Faraoni, N. (2020). Meta-ranking to position world universities. Studies in Higher Education, 45(4), 819-833.

Marr, K. A., Mullin, C. H., \& Siegfried, J. J. (2005). Undergraduate financial aid \& subsequent alumni giving behavior. Quarterly Review of Economics and Finance, 45, 123-143.

McFadden, D. L. (1984). Econometric analysis of qualitative response models. Handbook of econometrics, 2, 1395-1457. 
McLinden, M. (2017). Examining proximal and distal influences on the part-time student experience through an ecological systems theory. Teaching in Higher Education, 22(3), 373-388.

Mollick, E. (2014). The dynamics of crowdfunding: an exploratory study. Journal of Business Venturing, 29(1), $1-16$.

Naidoo, R., \& Williams, J. (2015). The neoliberal regime in English higher education: charters, consumers and the erosion of the public good. Critical Studies in Education, 56(2), 208-223.

Năstase, P. (2018). Hidden in plain sight: student fund-raising in Romanian universities. International Review of Social Research, 8(1), 47-54.

Nwakpuda, E. I. (2020). Major Donors and higher education: are STEM donors different from other donors? Nonprofit and Voluntary Sector Quarterly, 49(5), 969-988.

Parker, L. D. (2013). Contemporary university strategising: the financial imperative. Financial Accountability \& Management, 29(1), 1-25.

Planells, A. J. (2017). Video games and the crowdfunding ideology: from gamer-buyer to prosumer-investor. Journal of Consumer Culture, 17(3), 620-638.

Prazeres, L. (2019). Unpacking distinction within mobility: social prestige and international students. Population, Space and Place, 25(5), e2190.

Rifkin, J. (2014). The zero marginal cost society. New York: Palgrave Macmillan.

Sá, C., Florax, R. J. G. M., \& Rietveld, P. (2012). Living arrangement and university choice of Dutch prospective students. Regional Studies, 46(5), 651-667.

Sargeant, A., \& Jay, E. (2014). Fundraising management: analysis, planning and practice. London: Routledge.

Sauermann, H., Franzoni, C., \& Shafi, K. (2019). Crowdfunding scientific research: descriptive insights and correlates of funding success. PLoSONE, 14(1), e0208384.

Schafer, M. S., Metag, J., Feustle, J., \& Herzog, L. (2018) Selling science 2.0: what scientific projects receive crowdfunding online? Public Understanding of Science 27(5): 496-514.

Shaker, G. G., \& Nathan, S. K. (2017). Understanding higher education fundraisers in the United States. International Journal of Nonprofit and Voluntary Sector Marketing, 22(4), e1604.

Smith, S., Windmeijer, F., \& Wright, E. (2015). Peer effects in charitable giving: evidence from the (running) field. The Economic Journal, 125(585), 1053-1071

Stiver, A., Barroca, L., Minocha, S., Richards, M., \& Roberts, D. (2015). Civic crowdfunding research: challenges, opportunities, and future agenda. New media \& society, 17(2), 249-271.

Sturgis, P., \& Allum, N. (2004) Science in society: re-evaluating the deficit model of public attitudes. Public Understanding of Science 13(1): 55-74.Szkuta, K. \& Osimo, D. (2016) Rebooting science? Implications of science 2.0 main trends for scientific method and research institutions, Foresight 18(3): 204-223.

Teixeira, P., \& Landoni, P. (2017). The rise of private higher education: patterns of development and regulatory challenges. In P. Teixeira, S. Kim, P. Landoni, \& Z. Gilani (Eds.), Rethinking the public-private mix in higher education: global trends and national policy challenges (pp. 21-34). Rotterdam: Sense Publishers.

Teixeira, P., \& Koryakina, T. (2013). Funding reforms and revenue diversification-patterns, challenges and rhetoric. Studies in Higher Education, 38(2), 174-191.

Younkin, P., \& Kuppuswamy, V. (2018). The colorblind crowd? Founder race and performance in crowdfunding. Management Science, 64(7), 2973-3468.

Vismara, S. (2016). Equity retention and social network theory in equity crowdfunding. Small Business Economics, 46, 579-590.

Warren, A., Hoyler, M., \& Bell, M. (2016). From 'shadowy cabal' to new profession: networks of cooperation and competition in UK higher education fundraising. Environment and Planning C: Government and Policy, 34(5), 837-854.

Worth, M. J., Pandey, S., Pandey, S. K., \& Qadummi, S. (2020). Understanding motivations of mega-gift donors to higher education: a qualitative study. Public Administration Review, 80(2), 281-293.

Wright, E., \& Horta, H. (2018). Higher education participation in "high-income" universal higher education systems: "survivalism" in the risk society. Asian Education and Development, 7(2), 184-204.

Publisher's Note Springer Nature remains neutral with regard to jurisdictional claims in published maps and institutional affiliations. 


\section{Authors and Affiliations}

\section{Hugo Horta ${ }^{1}$ (D) . Michele Meoli ${ }^{2}$ (D) . Silvio Vismara ${ }^{3}$ (D)}

\section{Hugo Horta}

horta@hku.hk

Silvio Vismara

silvio.vismara@unibg.it

1 Social Contexts and Policies of Education, Faculty of Education, The University of Hong Kong, Hong Kong SAR, China

2 Department of Management, Information and Production Engineering, University of Bergamo, Bergamo, Italy

3 Department of Management, University of Bergamo, Bergamo, Italy 